\title{
The Feasibility of Farmer-Led Cooperatives for Southwest Florida Farm to School Procurement ${ }^{1}$
}

\author{
Jonathan Adam Watson, Danielle D. Treadwell, Catherine Campbell, and Ray Bucklin²
}

\section{Abstract}

Florida's small- and mid-sized farms produce many fruits and vegetables that are typically sold directly to consumers at farmers' markets, at farm stands, and through community-supported agriculture programs. Florida's K-12 schools provide a potential opportunity to increase market channel options for these diversified farms, but processing, storage, and distribution resources are extremely limited for smaller producers. The authors conducted a feasibility study based on data from 11 southwest Florida counties that included market, organizational, technical, and financial analyses of farmer-led cooperatives at three scales. This document serves as a model and case study with steps for producers and other stakeholders to conduct a feasibility study before forming a cooperative to sell local fruits and vegetables to schools and other institutional food-service outlets. Although this publication presents an analysis of factors necessary for ascertaining the feasibility of a farmerled cooperative to service schools and other institutions, it does not focus on how to complete a feasibility study.

\section{Introduction}

In Florida, sales from a small number of large farms comprise most of the state's agricultural receipts. The majority (97\%) of farms are considered small- and midsized ( $<\$ 500,000$ gross annual sales), according to the US
Department of Agriculture (2020). Owners and operators of small farms often face challenges that their larger counterparts do not experience because their business assets or crop production volume (sales) are insufficient to access or qualify for resources such as contract pricing, credit, and institutional markets. One benefit that small- and mid-sized farm businesses have is that they can offer a variety of diversified specialty crops, often unique in color or flavor, as fresh or minimally processed products (Swisher and Sterns 2003). Diverse and unique product lines can be leveraged to create new marketing opportunities and business models that enable small- to mid-sized farm operators to meet consumer needs that are currently not well addressed in the food system. Local Farm-to-School (F2S) procurement, or the purchase of food from area farms for cafeteria service, is one such need that, if realized, could provide a lucrative new market opportunity for Florida farmers.

In 2016, 29\% of Florida's 67 school districts served local fruit while $27 \%$ served local vegetables in cafeterias (US Department of Agriculture 2016). Although these percentages are higher than in other states, Florida has unique characteristics that provide opportunities to expand F2S. These characteristics include a mild climate, peak production of specialty crops during the school year (as opposed to summer when school is out elsewhere in the United States), and year-round production. However, sales to schools

1. This document is AE555, one of a series of the Department of Agricultural and Biological Engineering, UF/IFAS Extension. Original publication date March 2021. Visit the EDIS website at https://edis.ifas.ufl.edu for the currently supported version of this publication.

2. Jonathan Adam Watson, assistant professor, agricultural economics and postharvest, Department of Agricultural and Biological Engineering; Danielle D. Treadwell, associate professor, Horticultural Sciences Department; Catherine Campbell, assistant professor, community food systems, Ph.D., Department of Family, Youth and Community Sciences, UF/IFAS Mid-Florida Research and Education Center; and Ray Bucklin, professor emeritus, Department of Agricultural and Biological Engineering; UF/IFAS Extension, Gainesville, FL 32611.

The Institute of Food and Agricultural Sciences (IFAS) is an Equal Opportunity Institution authorized to provide research, educational information and other services

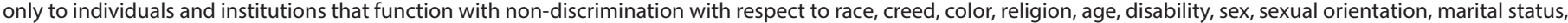

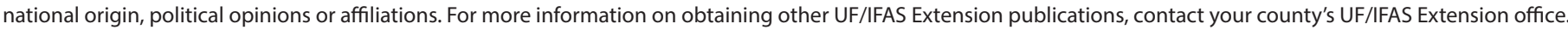
U.S. Department of Agriculture, UF/IFAS Extension Service, University of Florida, IFAS, Florida A \& M University Cooperative Extension Program, and Boards of County Commissioners Cooperating. Nick T. Place, dean for UF/IFAS Extension. 
are limited in part by supply-chain logistics (Izumi et al. 2010; Ohmart 2002), and small- to mid-sized farms have limited ability to aggregate, transport, minimally process, or provide other services (e.g., packaging) that schools require (Watson et al. 2018).

One potential method of organization to help Florida's small- to mid-sized producers sell to F2S would be farmer-owned agricultural cooperatives. Farmer-owned agricultural cooperatives are a business and marketing model in which individual farmers come together to operate a business for the mutual benefit of farmer members and where profit is not necessarily the primary goal. Farmer cooperatives strengthen the farmers' bargaining power, manage risk, provide access to new or competitive markets that would not otherwise be available to the farmers, and potentially reduce costs through economies of scale (National Council of Farmer Cooperatives 2020).

This publication is designed for small- and mid-sized farm operators, institutional food buyers, Extension educators, and other food-system stakeholders interested in developing new opportunities for farm-to-cafeteria markets. It describes a research project that explores the viability of creating a farmer-led cooperative in Florida to take advantage of F2S opportunities and expand local food procurement.

\section{Cooperative Feasibility Study}

In 2015, UF researchers conducted semi-structured interviews of farmers in 11 counties in southwest Florida (Watson et al. 2020). The producers in this study identified F2S as an appealing market opportunity, described distribution needs, and expressed an interest in participating in a farmer-led cooperative. Therefore, a feasibility study was conducted to determine the viability of a farmer-led cooperative in the region. The study analyzed market, organizational, technical, and financial components of the cooperative using data from the same counties where the farmers were interviewed. Initial values for technical considerations and financial projections used in this feasibility study were based on the following:

1. Data obtained from the Sarasota County School District (SCSD), which describe in detail significant growth in local food expenditures,

2. Estimates for known infrastructure, equipment, and labor costs, and
3. Assumptions about changes in sales, capacity, and service levels (Watson et al. 2018).

The feasibility study was organized into sections focused on market, organizational, technical, and financial analyses, with each component of the study intended to support the previous section in a logical progression, based on the assumption that the preceding section was feasible. The market analysis uses food procurement and enrollment data obtained from the SCSD as a measure of demand, volume, and food expenditures. The organizational analysis defines the legal and corporate structure of the cooperative and describes background information about the memberowners, including what skills they can contribute to the business. The technical analysis includes a buffer analysis that identifies an ideal location for a facility and describes necessary infrastructure and equipment at three different proposed scales. Finally, the financial analysis includes a list of key cost considerations and compares net proceeds for each of the three different cooperative scales. Each component is discussed in more detail below.

\section{Market Analysis}

For the market analysis, the target client was assumed to be the SCSD, which manages food procurement for each public school within the county, including 38 elementary, middle, and high schools. Another 23 private, charter, special needs, and alternative schools, as well as several institutions of higher education (e.g., New College and Ringling School of Art and Design), operate in the county and are also considered potential customers; thus, they were also included in the study.

Schools participating in the National School Lunch Program (NSLP) receive additional reimbursement from the federal government for each free and reduced-price meal served if a certain percentage of students qualify. Free and reduced-price lunches are subsidized for the student; however, eligible schools participating in the NSLP with $60 \%$ or more students receiving free or reduced-price lunches are eligible for an additional reimbursement of six cents per meal. Performance-based reimbursements to schools in the amount of 7 cents per meal served are available to schools that conform to the current meal pattern requirement, which provides opportunities for producers to meet this market demand through diverse product offerings, many of which qualify. Changes in annual enrollment and the number of free and reduced-price lunches served are a measure of potential demand because of the aforementioned reimbursements. Furthermore, changes in the 2008 Farm Bill encouraged schools to purchase locally grown 
and raised unprocessed agricultural products by applying geographic preference during the procurement process. In effect, the geographic preference option provides districts with flexibility in choice of local options and a competitive advantage to local producers in a way that does not restrict free and open competition.

Figure 1 shows an increase in the number of students as well as a general increase in the percent change in the number of reduced-price meals served. Although the change in the number of students is modest, the general increase in the number of free and reduced-price meals suggests larger reimbursements totals and food budgets. Coupled with incentives to purchase more local foods, dedicated school district staff supporting and facilitating greater F2S procurement efforts, and year-round availability of competitively priced food, the potential for growth is significant as local foods still represent only a fraction (32.1\%) of total food purchases in the region (Watson et al. 2018).

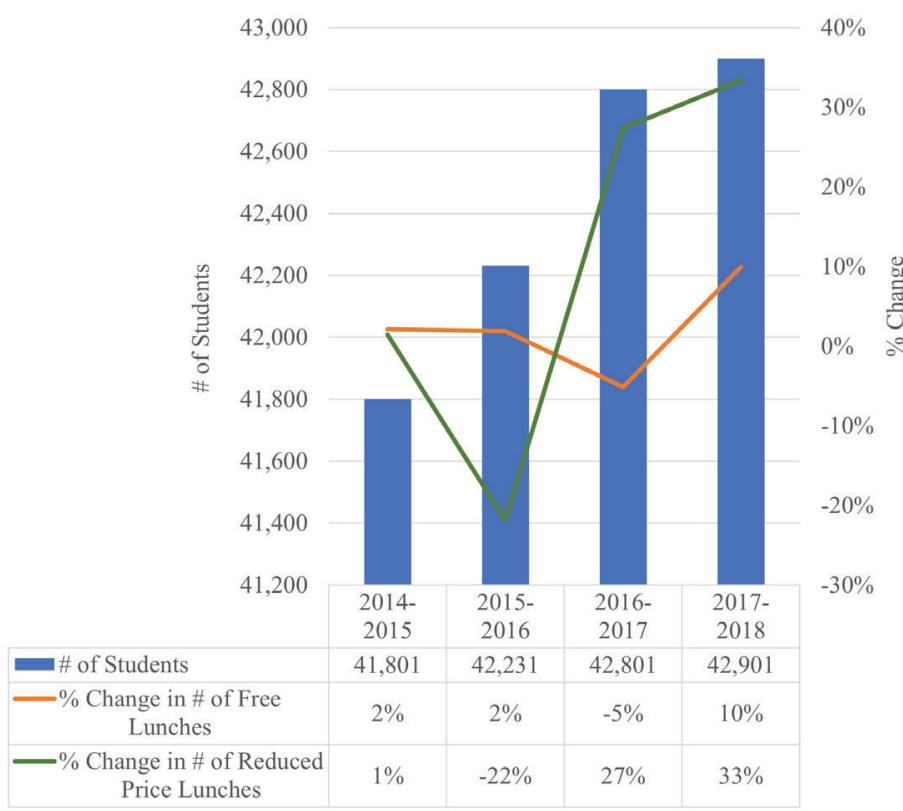

Figure 1. The number of students and the percent change in the number of free and reduced-price lunches served from 2014 to 2018 in the Sarasota County School District.

Credits: J. A. Watson, UF/IFAS

\section{Organizational Analysis}

The organizational section in a feasibility study usually outlines whether a proposed business has sufficient management experience, organizational competence, and resources to successfully launch the business. For the organizational analysis in this hypothetical scenario, we developed a model structure (Figure 2) outlining minimum administration and personnel requirements to ensure success. Admittedly, each cooperative has unique circumstances that would require different approaches, but the core of the structure would be similar for any given cooperative. The cooperative would pool resources from its members with help from management and under the guidance of a board of directors (BOD). The producers comprise the general assembly and elect the BOD. The BOD forms various committees who, in turn, delegate responsibilities to hired management. In our example, the BOD includes an executive committee made up of the chairman, vice-chairman, treasurer, and secretary. The marketing committee is responsible for generating interest in the cooperative's products. The elections committee would be responsible for overseeing the implementation of election procedures. Finally, the operations committee is responsible for overseeing operations from a strategic level. Although it is impossible to account for all items, key costs of hired management and personnel needed to operate the cooperative are included in the subsequent financial analysis, while member-owners contribute their time, expertise, and patronage.

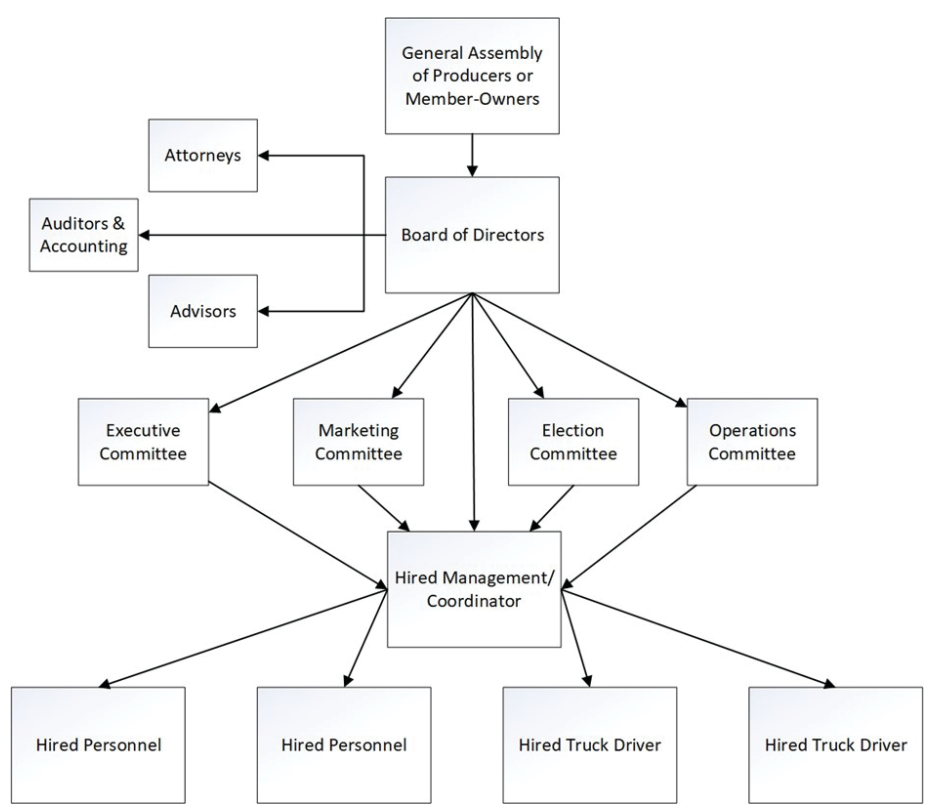

Figure 2. The organizational structure of a proposed marketing cooperative for F2S procurement. Producers or member-owners form the general assembly. The elected members of the board of directors form various committees that delegate responsibility to hired management who, in turn, delegate to hired personnel and truck drivers.

Credits: J. A. Watson, UF/IFAS

Membership in the cooperative would be open to all producers who qualify, pay membership fees, and meet ownership requirements (e.g., land or capital) established by the cooperative and its bylaws. The cooperative's BOD should consist of an odd number of elected members (suggested: five or seven) to eliminate tied votes. Hired management should consist of at least one facility manager or coordinator who possesses the skills necessary to meet 
the needs of the cooperative and its members. Ideally, hired personnel should be passionate and dedicated to achieving the goals and objectives of the cooperative. This proposed organizational structure provides producers a voice in the decision-making process and allows them to share the cost and benefits of the facility and the staff. Specific requirements for the management and hired personnel are outlined in the technical analysis below.

\section{Technical Analysis}

\section{Scale}

The technical requirements of a cooperative facility to serve school districts are mainly dependent on scale. For this analysis, we considered three scale-dependent facilities, each with different technical requirements, based on the assumptions listed in Table 1. The scale of a cooperative is determined by the level of specialization, efficient capital, bargaining or negotiation power, and facility size. In this study, we highlight facility size as the primary factor to differentiate scale because the level of specialization, capital, and negotiation power all depend on the volume of product the cooperative could process. All scales would have forklifts, washing and drying stations, and office areas. A smallscale cooperative facility would have limited equipment and ability to process food products; therefore, its output would be low, and the facility would capture a relatively small portion of the total sales of locally produced foods purchased by the school district. A medium-scale facility would be able to accommodate more producers and a higher product volume. The medium-scale warehouse would also have more equipment for sorting, minimal processing, and packaging than a small-scale facility. A large-scale cooperative warehouse facility would have even more capacity for storage and an even greater variety of equipment to handle and minimally process food products. While the facility would be able to handle a greater volume of product, it would undoubtedly require more infrastructure, resources, and personnel to operate and therefore incur more costs. Regardless of scale, each facility would require cold storage units to maintain optimal storage temperature and quality; however, the small-scale facility would not have the ability to process (i.e., chop, dice, cut, etc.) product. Depending on scale, the facility would require varying numbers of managers or coordinators to oversee operations and manage administrative tasks; laborers to receive, aggregate, and package product; and delivery drivers to transport products to customers. Because each cooperative business is unique, the quantity and quality of management, personnel, and equipment will vary. Furthermore, it is beyond the scope of this publication to identify all factors necessary for success.
Instead of providing specific recommendations and a comprehensive list, we identify, characterize, and in some cases, quantify several critical technical factors for the early stages of the formation of a farmer-led cooperative.

\section{Transportation}

Each scenario would require at least one delivery truck to transport products from the warehouse to the schools, or in some cases, to pick up products from the farm and deliver them to the warehouse. Regarding the delivery truck, there are various aspects to consider, including dimensions and specifications, materials, insulation, and airflow. For example, a leased truck selected for specific size requirements and period of use will reduce capital expenses in early years. A 24-foot refrigerated truck typically weighs between 4,200 and 4,650 lb, depending on the truck's exterior body height. A larger truck could hold more product and would need to make fewer return trips to the warehouse to load or unload. The exterior body width of the truck is most often 96 inches but could be 102 inches. Other important considerations are truck door options, foam insulation thickness, and flooring material. A two-panel full opening door is recommended because it will have better insulation than an overhead door with a latch, and it will reduce cold air loss. Foam insulation thickness varies inversely with interior truck body width. The wider the foam insulation, the narrower the inside of the truck; however, it is important to ensure that the truck is equipped with the appropriate insulation to maintain near-constant temperature and critical airflow. Insulation ensures the products will reach their destination with the highest quality possible.

\section{Personnel}

Hired management should consist of one facility manager/ coordinator who possesses the skills necessary to meet the needs of the cooperative and its members. The primary responsibilities of hired management will be organizing and supervising operational processes, motivating personnel, coordinating orders, and scheduling. Management is also responsible for setting goals and objectives for the various day-to-day operations, designing and implementing various operating procedures, protocols, and methods, and making financial projections. In most cases, management will develop the goals and objectives with the assistance of the BOD. These functions are accomplished with the goal of maximizing net proceeds or benefits to members. Management will develop charts for personnel that will outline their responsibilities, including the expected number of work hours, job description, and levels of performance. Additionally, management will be responsible for ensuring that all processing activities, sales accounts, and scheduling 
are organized in such a way that they meet the goals and objectives of the cooperative and its members. Management will also be responsible for conducting staff meetings and training exercises that improve worker productivity and competence.

Hired personnel would include warehouse personnel and truck drivers. First and foremost, hired personnel should be informed and have a clear understanding of the goals, objectives, and expectations of the cooperative. Ideal hired personnel should be passionate and dedicated to achieving the cooperative's goals and objectives. Management will create incentives to motivate hired personnel; however, they expect that all personnel perform their duties as the job description requires. Warehouse personnel are responsible for a variety of tasks, such as interacting with assisting members by unloading product brought to the warehouse for storage. Hired personnel will be responsible for answering calls, taking orders, and interacting with customers. Lifting heavy objects (often heavier than $50 \mathrm{lb}$ ) is required, as is operating forklifts and other processing and warehouse equipment (dollies, lifts, etc.). Truck drivers are expected to have a Class A or B Commercial Driver License (CDL). At the warehouse, truck drivers will need to be proficient in handling and lifting large boxes as well as operating dollies and/or forklifts to move product on and off the truck. Truck drivers must comply with all safety standards while driving. This includes the handling of fresh food products, particularly fresh produce, because they are easily damaged. Because the truck is refrigerated (i.e., "reefer"), the truck driver will be responsible for monitoring the environmental conditions in the truck, paying close attention to product quality.

\section{Location}

Each scale-dependent scenario will have a few features in common. For example, location is a critical component of each scale. For the purposes of assessing the location for F2S, the warehouse should be located near schools as well as major transportation routes with access to producers. The warehouse should also accommodate cold-storage equipment and have an easily accessible loading dock. Industrially zoned properties typically fit the requirements listed above. Through the layering of industrial zone properties, school locations, and buffer analysis, a general location for the facility was identified (Figure 3). Other location methods and tools such as network, neighborhood, and business analyses within geospatial software packages are available, but they often require specific information not known in the early stages of planning. A buffer analysis is a simple procedure that can be applied to any location to visualize features and distances in relation to one another; however, it is only useful when drive time is not a concern. Most industrial properties located in Sarasota County are concentrated in the northwestern part of the county just south of Dr. Martin Luther King Jr. Way and Fruitville Road and west of N Tuttle Avenue. This area provides convenient access to important transportation routes in the area such as US-301 and US-41. Located near SR-780, industrial property in this area is within a 15-minute drive of Interstate 75. Property located in this industrial area is an important consideration because most farms within the area will likely use SR-780 and Interstate 75 to deliver their products to the warehouse. Additionally, schools within Sarasota County are mostly concentrated in the northern part of the county. Therefore, this area would be the logical location for the proposed warehouse.

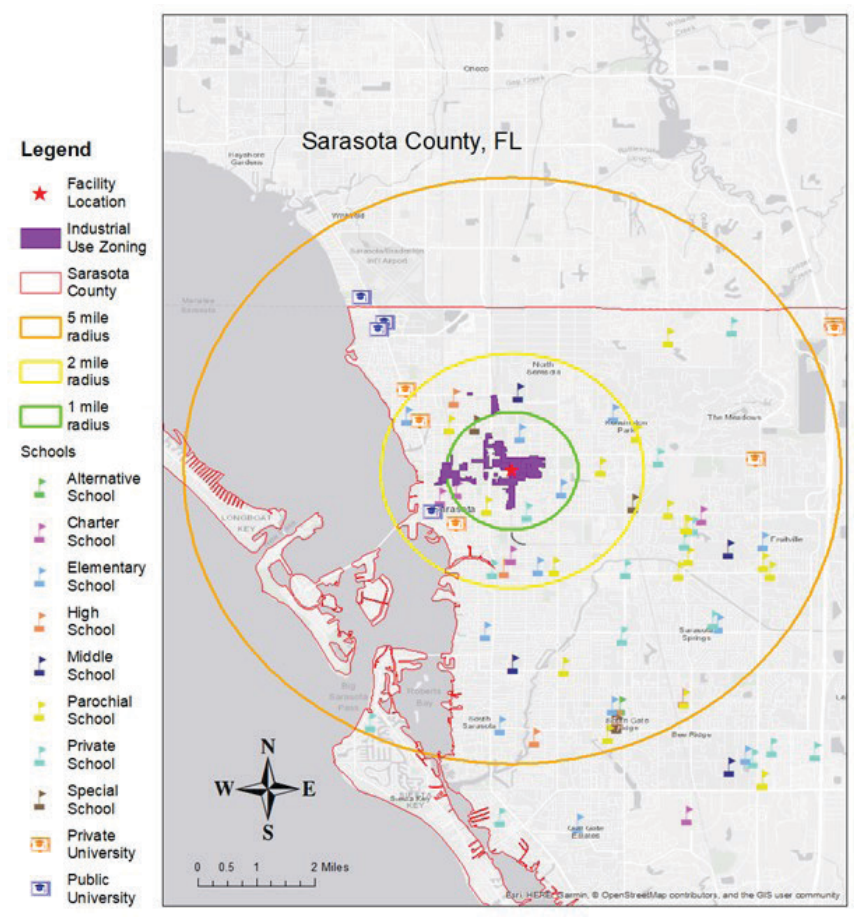

Figure 3. Buffer analysis of industrial zone properties with a proposed location for a member-owned cooperative facility to aggregate, process, package, and distribute locally produced food. Distances are included at 1-, 2-, and 5-mile radii in relation to public and private $\mathrm{K}-12$ schools, charter schools, and universities from the center of the proposed location.

Credits: J. A. Watson, UF/IFAS

\section{Financial Analysis}

The financial analysis is a critical component of any feasibility study. Cooperatives are financed in several ways (e.g., collecting operating funds from membership fees, raising equity from sale of common or preferred stock, selling bonds, and borrowing from banks), but cooperatives may also employ a "revolving capital" method where members make capital contributions proportional to their patronage 
(Knapp 1944). Where cooperative finance differs from conventional business is that members use and own the cooperative business (Peterson 2019). This has implications for net proceeds, which are paid largely with respect to patronage and not capital and occur at the member level and not cooperative level.

Developing a detailed financial model for an F2S aggregation, processing, and distribution to assess potential benefits and costs for an integrated, direct method of food supply is challenging. Each proposed model would differ in size and require varying levels of personnel, equipment, and professional fees as well as warehouse area and cold storage. As a result, the costs for each cooperative model would vary. For our analysis, the total amount spent on local food purchases by the SCSD is assumed to be identical for all scales, regardless of how the amount is allocated among the supply-chain participants (i.e., producers, aggregators, or distributors); therefore, total food purchases were kept constant in order to illustrate differences at facility scale. Based on school district purchasing data, an initial value of $\$ 263,947$ for all local fruits and vegetables purchased by the SCSD was used to forecast yearly gross annual sales for the cooperative (Watson et al. 2018). In this context, gross sales are the amount of sales generated for all local food products sold to the SCSD, regardless of supplier.

Because it is unlikely that a cooperative at any scale would be able to supply the school district with all its local food products, we expect that some products will be sourced from other vendors. A larger cooperative facility can handle greater volumes of local product; therefore, school districts can rely less on other vendors such as wholesale distributors. For this financial analysis, a constant value for local food purchases by the SCSD at each facility scale is assumed; however, the percent of sales that flows to each supplier will be different depending on the scale or size of the cooperative and its facilities. For example, a large-scale cooperative would be able to handle more product and therefore earn greater sales (assumed at 75\% of total sales), whereas a small-scale cooperative would only be able to capture a fraction (assumed at 25\%) of the total local food purchased by SCSD. A portion would be captured by the distributors. Gross sales for year 1 and each subsequent year have an assumed growth rate of $10 \%$, which is a conservative estimate for a new business. Although growth rates may be negative in some years, they are typically higher for new businesses in earlier years than later years. To simplify our analysis, a constant growth rate was used each year. We chose $10 \%$ based on a review of several publications that reported growth rates for agricultural cooperatives ranging from $-16 \%$ to $15 \%$, annually where a growth rate of $10 \%$ was observed for farm cooperatives in Kansas from 1997 to 2014 (Smart and Briggeman 2017; Bérubé et al.

2012). Finally, it is assumed that the larger the cooperative, the greater share of sales they will require to cover their expenses. Several key expense items for launching and operating the cooperative are included in Table 2.

Cost of goods sold, which includes the value of raw products, is not included in this analysis. It is often the case that with a marketing or producer cooperative, the cost of goods sold is omitted from the financial analysis. Cooperatives do not record the cost of goods sold as a liability and report net proceeds instead of standard net profit (Figure 4). Although net proceeds and net profit both refer to the amount of sales remaining after paying all expenses, net proceeds are frequently used by cooperatives when reporting income because generating profit is not always the primary objective. Cooperatives will often append a separate section to their income statement that details how net proceeds were distributed to the cooperative or among its members. This distribution is in the form of cash, accounts payable to its members, retained earnings for the cooperative. Regardless, the empirical analysis shows that financial statements of cooperatives that do not report the cost of goods sold have profitability estimates and ratios that are comparable to businesses that report conventional net margins (Lerman and Parliament 1990). However, for this analysis, the assumption is that all net proceeds are distributed to its members.

Figure 4 highlights the importance of scale when considering the financial feasibility of a proposed cooperative. Due to the low volume that a small-scale cooperative can process, such a cooperative will not be able to cover its expenses, which is especially problematic during certain months (i.e., when schools are out of session or when local food is unavailable). As a result, a large percent of the school district's sales (assumed 50\%) will be captured by the distributors and other vendors. Costs will be kept low because fewer trucks, personnel, equipment, and cold-storage capacity are required; however, the smallscale cooperative model will not be profitable in the first five years of its existence because it is operating at such a small scale and lacks the volume required to generate enough sales to cover annual costs, resulting in negative net margins. The medium- and large-scale cooperatives will perform much better after several years. In year 4 , the cooperative will break even in the medium- and large-scale cooperative scenarios. In year 5, net proceeds are estimated at roughly $8 \%-10 \%$. 


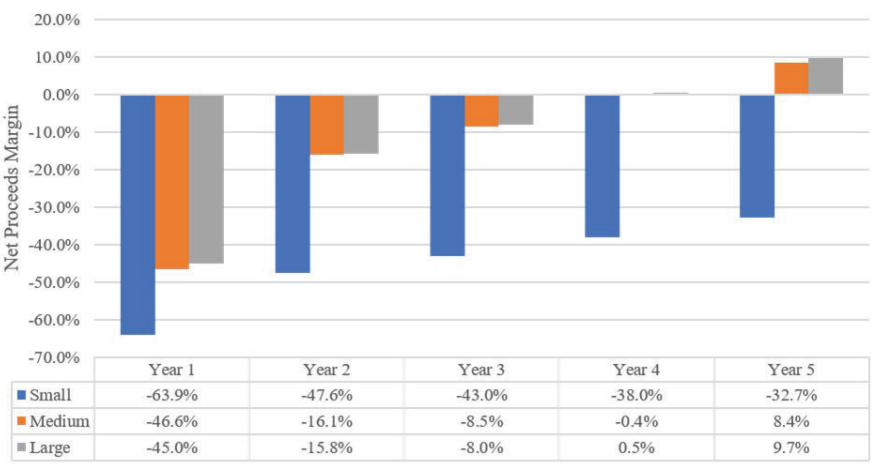

Figure 4. Scale-dependent sensitivity analysis of net proceeds for proposed cooperative operations and facilities.

Credits: J. A. Watson, UF/IFAS

\section{Conclusion}

This analysis highlighted the potential benefits of participating in F2S procurement as well as the feasibility of a farmer-led cooperative to make that participation possible. The steps in the feasibility study included an analysis of the market and organizational, technical, and financial aspects of the potential cooperative. The paper provides estimates for personnel and capital costs, an analysis used to identify an ideal location, infrastructure, and equipment, and an overview of necessary skills of hired personnel and management. Definitions of legal and corporate requirements in the form of an organizational analysis and a market analysis consisting of food procurement and student enrollment data were used to forecast demand. The results of our analysis support the conceptualization and development of a farmer-led F2S cooperative based on the specific needs and opportunities of area farmers and local market dynamics in the Sarasota County region, but these findings may be applicable to other areas. The steps utilized in this study may be applied to other school districts or in other contexts where small- and mid-sized producers are interested in serving institutional markets and need to assess infrastructure and investment needs where forming a cooperative may be an advantageous model of procurement and distribution.

The authors hope that this analysis serves as a model for producers interested in forming cooperatives to sell local fruits and vegetables to schools. Although outlining specific steps to conducting a feasibility study is not the focus of this paper, the components of a feasibility study are often sequential because they describe key actions and detail criteria for selecting resources, personnel, and equipment or identifying an ideal location in succession. This publication may serve as a case study and guide to initial steps in developing more detailed, comprehensive studies to form cooperatives to help small- and mid-sized farms meet institutional demand for local food. For more information on developing feasibility studies, see Vital Steps: A Cooperative Feasibility Study Guide (http://sfp.ucdavis.edu/ files/272225.pdf).

\section{References}

Bérubé, V., A. Grant, and T. Mansour. 2012. "How Cooperatives Grow." In McKinsey on Cooperatives. https://www. mckinsey.com/ /media/mckinsey/dotcom/client_service/ Strategy/McKinsey on Cooperatives/PDFs/McK_on_Cooperatives-How_cooperatives_grow.ashx

Izumi, B. T., D. W. Wright, and M. W. Hamm. 2010. "Farm to School Programs: Exploring the Role of RegionallyBased Food Distributors in Alternative Agrifood Networks.” Agriculture and Human Values 27 (3): 335-350. https://doi. org/10.1007/s10460-009-9221-x

Knapp, J. G. 1944. "How Are Cooperatives Financed?” In Why Co-ops? What Are They? How Do They Work? https:// www.historians.org/about-aha-and-membership/ahahistory-and-archives/gi-roundtable-series/pamphlets/em23-why-co-ops-what-are-they-how-do-they-work-(1944)/ how-are-cooperatives-financed

Lerman, Z., and C. Parliament. 1990. Estimating the Accounting Profitability of Pooling Cooperatives. University of Minnesota.

National Council of Farmer Cooperatives. 2020. "About NCFC." http://ncfc.org/about-ncfc/

Ohmart, J. 2002. "Direct Marketing to Schools: A New Opportunity for Family Farmers." In University of California Sustainable Agriculture Research and Education Program.

Peterson, C. 2019. "Cooperative Financing." https://cooperatives.extension.org/cooperative-financing/

Smart, N., and B. C. Briggeman. 2017. "Sustainable Growth Rates for Cooperatives." Kansas State Agricultural Economics Arthur Capper Cooperative Center. https://accc.k-state. edu/research/factsheets/FS11_SustainableGrowthRates.pdf

Swisher, M., and J. Sterns. 2003. "An Overview of Small Farm Direct Marketing." EDIS 2003 (10). https://doi. org/10.32473/edis-fy597-2003

US Department of Agriculture. 2016. "2015 USDA Farm to School Census." https://farmtoschoolcensus.fns.usda.gov/ data-explorer 
US Department of Agriculture National Agricultural

Statistics Service. 2020. "Farms and Land in Farms 2019

Summary." https://www.nass.usda.gov/Publications/

Todays_Reports/reports/fnlo0220.pdf

Watson, J. A., D. D. Treadwell, and R. A. Bucklin. 2018.

"Economic Analysis of Local Food Procurement in

Southwest Florida's Farm to School Programs." Journal of

Agriculture, Food Systems, and Community Development 8

(3): 61-84. https://doi.org/10.5304/jafscd.2018.083.011 
Table 1. Assumptions for technical requirements of warehouse facilities, equipment, and personnel by scale.

\begin{tabular}{|c|c|c|c|c|c|c|}
\hline \multirow[b]{2}{*}{ Warehouse facility } & \multicolumn{2}{|c|}{ Large-Scale Facility } & \multicolumn{2}{|c|}{ Medium-Scale Facility } & \multicolumn{2}{|c|}{ Small-Scale Facility } \\
\hline & $m^{2}$ & $\mathrm{ft}^{2}$ & $m^{2}$ & $\mathrm{ft}^{2}$ & $\mathrm{~m}^{2}$ & $\mathrm{ft}^{2}$ \\
\hline Total area & 371.6 & 4,000 & 185.8 & 2,000 & 92.9 & 1,000 \\
\hline Storage area & 185.8 & 2,000 & 92.9 & 1,000 & 46.5 & 500 \\
\hline Washing and drying area & 46.5 & 500 & 23.2 & 250 & 9.3 & 100 \\
\hline Processing area & 69.7 & 750 & 23.2 & 250 & 0 & 0 \\
\hline Packaging area & 46.5 & 500 & 23.2 & 250 & 4.6 & 150 \\
\hline Office area & 23.2 & 250 & 23.2 & 250 & 23.2 & 250 \\
\hline \multicolumn{7}{|l|}{ Personnel } \\
\hline Manager/Coordinator & \multicolumn{2}{|c|}{1} & \multicolumn{2}{|c|}{1} & \multicolumn{2}{|c|}{1} \\
\hline Personnel & \multicolumn{2}{|c|}{2} & \multicolumn{2}{|c|}{1.5} & \multicolumn{2}{|c|}{1} \\
\hline Truck drivers & \multicolumn{2}{|c|}{2} & \multicolumn{2}{|c|}{1} & \multicolumn{2}{|c|}{1} \\
\hline
\end{tabular}

Table 2. Key capital and operating expenses needed to launch a cooperative facility.

\begin{tabular}{|c|c|c|c|}
\hline Item & Description & Unit & Range of Costs (per unit) \\
\hline Warehouse & $\begin{array}{l}\text { A facility location of adequate size used for } \\
\text { wholesale storage of food for a certain period before } \\
\text { distribution to customers. }\end{array}$ & $\$ / \mathrm{ft}^{2} / \mathrm{month}$ & $\$ 0.70-\$ 1.60$ \\
\hline Cold storage & $\begin{array}{l}\text { Facilities used to store perishable product at } \\
\text { constant, colder temperatures. }\end{array}$ & $\$ / \mathrm{ft}^{2}$ & $\$ 150-\$ 170$ \\
\hline Produce washing station & $\begin{array}{l}\text { Equipment including a sink, water hose, and } \\
\text { drainage used to remove dirt and debris from freshly } \\
\text { harvested produce. }\end{array}$ & \$/unit & $\$ 1,250-\$ 2,000$ \\
\hline Produce processing equipment & $\begin{array}{l}\text { Various slicing, dicing, chopping, and shredding } \\
\text { equipment used to minimally process fresh produce. }\end{array}$ & \$/unit & $\$ 75-\$ 2,000$ \\
\hline Refrigerated truck & $\begin{array}{l}\text { Vehicle specially designed to carry perishable freight } \\
\text { at specific temperatures. }\end{array}$ & \$/vehicle/month & $\begin{array}{l}\$ 1,500-\$ 2,400+\text { mileage }+ \\
\text { fuel }\end{array}$ \\
\hline Manager/coordinator & $\begin{array}{l}\text { Oversees receiving, warehousing, distribution, } \\
\text { operations, administrative and scheduling tasks as } \\
\text { well as communicating orders with suppliers and } \\
\text { customers. }\end{array}$ & $\$ /$ year & $\$ 50,000-\$ 60,000$ \\
\hline Personnel & $\begin{array}{l}\text { Accepting delivery, inspecting, processing, and } \\
\text { preparing product for delivery. }\end{array}$ & $\$ /$ year & $\$ 30,000-\$ 35,000$ \\
\hline Truck driver & $\begin{array}{l}\text { Responsible for inspecting, driving, and operating } \\
\text { trucks and ensuring goods are picked up and } \\
\text { delivered as instructed. }\end{array}$ & $\$ /$ year & $\$ 30,000-\$ 40,000$ \\
\hline
\end{tabular}

